\title{
KEJAHATAN ASUSILA DALAM NOVEL DRUPADI KARYA SENO GUMIRA AJIDARMA
}

\author{
Hanan Nabila
}

Prodi Pendidikan Bahasa dan Sastra Indonesia

Universitas Muhammadiyah Malang

Hanannabila1@gmail.com

\begin{abstract}
ABSTRAK
Dalam novel yang berjudul Drupadi karya Seno Gumira Ajidarma berkisah tentang perjalanan hidup Drupadi yang luar biasa. Drupadi sosok wanita cerdas, kuat, dan kelembutannya mampu memberi perlawanan atas penghinaan dan kejahatan asusila yang dilakukan Kurawa. Drupadi digambarkan sebagai wanita poliandri yang hidupnya sengsara tapi ia tetap bersetia kepada takdir. Permasalahan yang disoroti oleh peneliti adalah tentang kejahatan asusila yang terjadi di dalam novel Drupadi karya Seno Gumira Ajidarma. Penelitian ini menggunakan metode deskriptif kualitatif untuk memberikan penjelasan yang terperinci dan mendalam mengenai suatu permasalahan sosial yang tedapat di dalam novel yang berjudul Drupadi karya Seno Gumira Ajidarma. Pendekatan yang digunakan dalam penelitian ini adalah sosiologi sastra. Sumber data dalam penelitian ini berupa novel Drupadi. Penelitian ini membahas mengenai bentuk-bentuk tindak kejahatan asusila dalam novel Drupadi karya Seno Gumira Ajidarma, Faktor-faktor penyebab kejahatan asusila dalam novel Drupadi karya Seno Gumira Ajidarma, dan keterkaitan pendidikan dan pengembangan karakter dalam pembelajaran Bahasa Indonesia melalui kearifan lokal. Berdasarkan hasil penelitian terhadap novel Drupadi karya Seno Gumira Ajidarma dapat disimpulkan bahwa bentuk-bentuk kejahatan sosial yang terjadi di dalam novel yaitu kejahatan perkosaan dan pelecehan seksual.
\end{abstract}

\section{Kata kunci : kejahatan asusila, pendidikan, novel. 1. PENDAHULUAN}

Novel merupakan salah satu jenis karya sastra yang digunakan pengarang untuk menggambarkan, mengekspresikan, dan mengkritik kenyataan sosial yang terjadi di sekitarnya. Hubungan antara satu orang dengan orang lain, antara perempuan dan lakilaki dalam masyarakat juga terdapat dalam sebuah novel yang terepresentasikan dalam tokoh-tokohnya. Pengarang menceritakan bagaimana relasi antara tokoh satu dengan tokoh lain, tokoh-tokoh dalam cerita dengan masyarakat. Berbagai macam konflik juga diciptakan pengarang didalam novel. Semi (dalam Kartika ， 1988:32) novel mengungkapkan suatu konsentrasi kehidupan pada yang tegang dan pemusatan kehidupan yang tegas.

Karya sastra merupakan seni yang bermediumkan bahasa dan tercipta melalui proses yang intensif, selektif, dan subjektif. Karya sastra sering menampilkan eksistensi perempuan serta persoalan-persoalan yang mewarnai perjalanan hidup perempuan. 
Persoalan tersebuat antara lain adalah ketidakadilan yang diterima oleh perempuan. Pada beberapa novel Indonesia, baik itu yang ditulis oleh penulis laki-laki ataupun perempuan, banyak yang menciptakan figur laki-laki menjadi the authority, sedangkan perempuan diletakkan sebagai warga kelas dua (the second sex) Edswara (dalam Dewi, 2003:143). Banyak tokoh perempuan diperlakukan semenah-menah oleh kaum lakilaki seperti kejahatan asusila. Sehingga kondisi ini membuat perempuan berada dalam posisi yang tertindas, dan tidak memiliki kebebasan.

Asal mula penindasan terhadap perempuan adalah patriarki Bhasin (dalam Aris Margono 1996:1). Partiarki digunakan secara lebih umum untuk menyebut sistem yang membuat perempuan tetap dikuasai melalui bermacam-macam cara. Laki-laki selalu berusaha menguasai perempuan. Wanita dibuat menjadi bergantung pada lakilaki. Hingga akhirnya para perempuan harus membela hak asasinya kepada laki-laki. Bahwa hak perempuan dan laki-laki adalah sama baik dalam bidang sosial, politik, dan ekonomi, maupun bidang kebudayaan umumnya. Kehormatan adalah persamaan dan keadilan dalam hak-hak manusia.

Kejahatan asusila adalah perbuatan yang menyimpang dari norma-norma kesopanan yang saat ini cenderung banyak terjadi di kalangan masyarakat. Ada banyak jenis-jenis kejahatan asusila yang akan dibahas oleh peneliti. Terutama peneliti lebih menyoroti kejahatan asusila mengenai pelecehan seksual. Fitzgerald dan Schullman (dalam Sulistyorini 1987:27), menyatakan bahwa bentuk-bentuk pelecehan seksual dapat dikelompokkan berdasarkan lima tingkatan yaitu: gender harrasment, seduction behaviour, sexsual bribery, sexsual coersion, dan sexsual imposition.

Dalam novel yang berjudul Drupadi karya Seno Gumira Ajidarma berkisah tentang perjalanan hidup Drupadi yang luar biasa. Drupadi sosok wanita cerdas, kuat, dan kelembutannya mampu memberi perlawanan atas penghinaan dan kejahatan asusila yang dilakukan Kurawa. Drupadi digambarkan sebagai wanita poliandri yang hidupnya sengsara tapi ia tetap bersetia kepada takdir. Permasalahan yang disoroti oleh peneliti adalah tentang kejahatan asusila yang terjadi di dalam novel Drupadi karya Seno Gumira Ajidarma. Murniat (dalam Sulistyorini 1995:9) mengemukakan bahwa pelecehan seksual adalah penyalagunahan hubungan perempuan dan laki-laki yang merugikan salah satu pihak, karena dilecehkan dan direndahkan martabatnya. Kejahatan asusila sama saja dengan merampas harga diri perempuan.

Maka dari itu masalah yang disoroti dalam novel drupadi adalah bentuk-bentuk kejahatan asusila. Peneliti akan mengungkap bentuk-bentuk kejahatan asusila sesuai dengan yang terjadi di dalam masyarakat. Dalam novel Drupadi karya Seno Gumira Ajidarma belum ada penelitian sebelumnya. 
Maka dari itu peneliti mencoba untuk mengungkap bentuk-bentuk kejahatan asusila yang diharapkan dapat bermanfaat bagi pengembangan dan pembelajaran sastra

Dengan demikian, maka penelitian ini dapat dikaji dengan menggunakan pendekatan sosiologi sastra untuk mengetahui kejahatan asusila yang tentunya berkaitan erat dengan kehidupan sosial. Kehidupan sosial dapat dikaitkan dengan kehidupan sosial dan latar belakang budaya. Sosiologi merupakan sebuah ilmu yang mempelajari gejala umum yang ada pada setiap interaksi antarmanusia. Adapun objek sosiologi menurut Soekanto (dalam Asriningsari, 1988:20) masyarakat yang dilihat dari sudut hubungan antarmanusia, dan proses yang timbul dari hubungan manusia di dalam masyarakat.

Pradopo (dalam Mayasari 2002:22) menambahkan bawa tujuan sosiologi sastra adalah untuk mendapatkan gambaran lengkap, utuh, dan menyeluruh tentang hubungan timbal balik antara pengarang sastra, karya sastra, dan masyarakat. Sosiologi sastra sangat berhubungan erat dengan masyarakat dan merupakan dua unsur penting yang tidak dapat dipisahkan. Maka dari itu dalam sosiologi selalu terjadi timbal balik baik dari pengarang, karya sastra, dan masyarakat.

\section{KAJIAN PUSTAKA}

Semiotik merupakan ilmu tentang tanda. Ilmu ini menganggap bahwa fenomena sosial/masyarakat dan kebudayaan itu merupakan tanda-tanda, semiotik itu juga mempelajari sistem-sistem, aturan-aturan, dan konvensi-konvensi yang memungkinkan tanda-tanda tersebut mempunyai arti (Pradopo, 2003:119). Konsep ini melihat bahwa makna muncul ketika ada hubungan yang bersifat ditandai dan menandai. Tanda merupakan kesatuan dari suatu bentuk penanda dengan sebuah ide atau petanda. Jadi, penanda adalah aspek material dari bahasa, yakni apa yang telah dikatakan atau didengar dan apa yang ditulis atau dibaca.

Pengkajian mengenai konteks dalam pemaknaan merupakan sebuah kerja yang menarik. Bukan karena dimensi kontekstualnya saja yang berbeda akan melahirkan makna yang berbeda, melainkan juga bahwa sebuah analisi semiotika akan mampu menggali hal-hal yang sifatnya subtle dari penggunaan bahasa seperti hanya tentang seperangkat nilai atau ideologi yang tersembunyi dibalik penggunaan bahasa. semiotik seringkali digunakan sebagai analisis yang mampu menampilkan bekerjanya ideologi dalam teks.

Jika dihubungkan dengan novel semiotika dapat berfungsi sebagai penjelas makna yang terdapat dalam novel tersebut melalui kejadian-kejadian yang terjadi didalam novel. Novel memuat penghayatan dan perenungan secara intens, penuh kesadaran dan tanggungjawab pengarang terhadap hakikat hidup dan kehidupan. Selain itu, di dalam novel juga memberikan 
pengalaman mengenai kehidupan di masa lalu, masa kini, maupun masa mendatang.

Karya sastra merupakan gambaran kehidupan manusia beserta lika-likunya. Penggambaran tersebut digambarkan melalui permasalahan-permasalahan yang terjadi dalam cerita. Pembaca sastra yang serius akan dapat menikmati kehidupan dalam karya sastra dengan terlibat yang sebenar-benarnya sehingga ia mampu mengungkapkan peristiwa yang ada sebagai bentuk penyatuan diri(Sugiarti, 2014).

\section{METODE}

Penelitian ini menggunakan metode deskriptif kualitatif untuk memberikan penjelasan yang terperinci dan mendalam mengenai suatu permasalahan sosial yang tedapat di dalam novel yang berjudul Drupadi karya Seno Gumira Ajidarma. Pendekatan yang digunakan dalam penelitian ini adalah sosiologi sastra. Sumber data dalam penelitian ini berupa novel Drupadi, data yang dianalisis mengenai kejahatan asusila yang terdapat di dalam novel tersebut. Teknik pengumpulan data yang digunakan dalam peneitian ini yaitu studi dokumen yang berupa 1) membaca dengan cermat keseluruhan isi novel Drupadi 2) mencatat hasil deskripsi. Teknik analasis yang digunakan dalam novel Drupadi adalah analisis isi. Teknik analisis ini mampu mendeskripsikan atau menggambarkan hasil analisis kejahatan asusila dalam novel Drupadi. Penelitian dengan metode analisis isi digunakan untuk menelaah isi dari suatu dokumen.

\section{PEMBAHASAN}

Di dalam novel Drupadi menceritakan seorang wanita yang dinikahi oleh lima ksatria pandawa. Namun, kehidupan Drupadi begitu sengsara. Ia mengalami kejahatan asusila yang dilakukan oleh para Kurawa sehingga Drupadi merasa terhina dan terlecehkan. Kejadian tersebut terjadi didepan suami-suaminya tetapi tidak ada yang membela Drupadi dan ia merasa kecewa terhadap suami-suaminya.

\section{Bentuk-Bentuk Tindakan Kejahatan} Asusila dalam Novel Drupadi Karya Seno

\section{Gumira Ajidarma}

Kejahatan asusila merupakan tindakan yang menyimpang terhadap norma, menggambarkan perbuatan dan pandangan si peleceh kepada yang dilecehkan dimana pandangan tersebut menghinakan, memandang rendah atau tidak berharga. berikut beberapa bentuk kejahatan asusila dan beberapa bentuk yang terjadi didalam novel antara lain:

\section{a. Perkosaan}

Memaksa orang lain untuk melakukan hubungan seks. Ini dapat terjadi pada orang yang dikenal atau tidak. Kejahatan asusila tersebut terlihat pada novel Drupadi kejadian tersebut terjadi ketika Drupadi digunakan sebagai taruhan dan kemudian Drupadi diperkosa oleh Kurawa. Menurut Sulistyaningsih \& Faturochman (dalam Fuadi 
, 2002) bagi korban perkosaan yang mengalami trauma psikologis yang sangat hebat, ada kemungkinan akan merasakan dorongan yang kuat untuk bunuh diri. Kebanyak trauma akibat perkosaan sering terjadi karena sangan menekan jiwa mereka sehingga merasa trauma yang cukup berat.

Kutipan dalam novel :

Para pandawa takberdaya.

Terhina dan hina.

Sorak sorai Kurawa semakin menggila.

"perempuan ini tak mau menyembahku,"

kata Duryudhana.

"Dursasana adikku telanjangi dia!"

Sekali sentak, lepaslah kain Drupadi, yang kali ini tidak mendapat perlindungan Kresna.

Ia dilemparkan ke atas meja Judi, dan Duryudhana di depan mata semua orang melepas pula kainnya, diiringi sorak sorai Kurawa. "Drupadi milik kita!"

Duryudhana yang pertama, lantas Durasasana, selanjutnya para Kurawa memperebutkannya...

Kutipan tersebut menggambarkan perlakuan tidak pantas yang dilakukan kepada seorang wanita yang seharusnya seorang wanita dihormati dan dilindungi bukan dipermalukan dan dilecehkan.

\section{b. Pelecehan seksual}

Penghinaan terhadap nilai seksual seseorang yang ada dalam tubuhnya. Hal itu dapat berupa ucapan, tulisan, tindakan yang dinilai mengganggu atau merendahkan martabat kewanitaan, seperti mencolek, meraba, mecium, mendekap. Berkaitan dengan pelecehan seksual, Danova (dalam 2001:8) berpendapat bahwa pelecehan seksual adalah bentuk dari tingkah laku laki-laki yang tidak mendapat balasan, tidak diminta, tidak diinginkan yang bertujuan merendahkan martabat perempuan karena memperlakukannya sebagai objek seks. Suatu tindakan semenah-menah yang sangat merugikan perempuan dan merampas kehormatan perempuan. Bentuk pelecehan seksual adalah pemerkosaan yang selalu menjadikan perempuan sebagai orang yang dilecehkan. Pelecehan seksual itu meliputi pandangan mata, komentar, pendapat maupun kontak fisik yang menimbulkan hasrat seksual yang tidak diinginkan, termasuk permintaan untuk melakukan hal-hal yang bersifat seksual. Dampak pelecehan seksual pada tokoh utama perempuan atau Drupadi. Tokoh Drupadi ingin membalas dendamnya atas pelecehan tersebut dan mebela hak-haknya sebagai seorang perempuan.

Dampak dari pelecehan seksual yang menimpa pada tokoh utama dalam novel Drupadi dapat diketahui bahwa perilaku seksual menyimpang yang teridentifikasi, yaitu perilaku perkosaan dan pelecehan seksual. Terbukti pada penggalan cerita dimana Drupadi diperkosa oleh para Kurawa, dan Drupadi merasa terhina dan ingin membalas dendam.

\section{Faktor-faktor Penyebab Kejahatan} Asusila dalam Novel Drupadi Karya Seno Gumira Ajidarma 
Faktor penyebab kejahatan asusila terjadi melalui berbagai macam faktor seperti faktor lingkungan, faktor pergaulan, faktor jaman, faktor psikologi dan faktor rendahnya moraitas, dan lain-lain. Dalam Novel Drupadi faktor yang menyebabkan terjadinya kejahatan sosial adalah faktor kekuasaan, dimana kekuasaan dapat merampas apa saja yang mereka inginkan dan bertindak semenah-menah.

Kutipan dalam novel :

"Justru itu Bima, besok kalian sudah pulang, mari kita berjudi habis-habisan," tantang Duryudhana, "Kupertaruhkan kereta emas, seribu gajah, dan seratus ribu kuda. Kalau paman Sangkuni kalah,kuberikan semuanya kepada kalian. Kalau kalah, kereta emas, seribu gajah, dan seratus ribu kuda kalian untukku.

Dapat disimpulkan bahwa mereka mempertaruhkan harta dan kekuasaan hingga negara dan Drupadi menjadi taruhan perjudian.

Faktor lingkungan karena kurangnya perhatian dari orang sekitar, sebuah lingkungan yang kurang bagus etika sosialnya.

Kutipan dalam novel :

Ia telah bersikap bebas dan berani sebagai putri raja, tetapi kini ia berada di tengah

lingkungan yang berbeda. Ia berada di sebuah gubuk bersama para ksatria yang terandaikan

telah memiliki hak atas dirinya, sesuai dengan perjanjian terhormat ayahnya tentang

kesatuan sayembara.
Faktor pergaulan dapat terjadi karena meniru perbuatan temannya, sebuah pergaulan yang sangat bebas sehingga dapat terjerumus dalam tindakan tersebut. Faktor jaman diamana bentuk-bentuk kejahatan asusila tersebut sudah marak terjadi di masyarakat. Faktor psikologi karena seseorang depresi atau stres sehingga bertindak apapun yang mejadikan mereka merasa senang. Faktor rendahnya moralitas yang tidak dapat bertumbuh dengan baik, membuat pelaku tidak dapat mengontrol nafsu atau perilakunya.

\section{Pendidikan dan pengembangan karakter} dalam Pembelajaran Bahasa Indonesia Melalui Kearifan Lokal

Penelitian tersebut dapat dihubungkan dengan pendidikan dan pengembangan karakter dengan melalui kearifan lokal. Kearifan lokal adalah pandangan hidup dan ilmu pengetahuan serta berbagai strategi kehidupan yang berwujud aktivitas yang dilakukan oleh masyarakat lokal dalam menjawab berbagai masalah pemenuhan kebutuhan mereka. Pendidikan merupakan suatu proses di mana suatu bangsa mempersiapkan generasi mudanya untuk menjalankan kehidupan dan untuk memenuhi tujuan hidup secara efektif dan efesien. Proses pendidikan yang profesional dapat membentuk karakter peserta didik. Karakterkarakter tersebut seperti kejujuran rasa hormat, kesetiaan, martabat, idealisme, berbudi luhur, kepatuhan, tanggung jawab, 
kerja sama, keberanian, kendali diri, dan lainlain. Karakter diri dilandasi nilai-nilai serta cara berpikir berlandaskan nilai-nilai tersebut dan terwujud dalam perilaku. Coon (Zubaedi, 2011: 8) mendefinisikan karakter sebagai suatu peneitian subjektif terhadap kepribadian yang dapat atau tidak dapat diterima masyarkat.

$$
\text { Zainal dan Sujak (2011: 2) }
$$

mengatakan karakter mengacu pada serangkaian sikap (attitudes), perilaku (behaviors), motivasi (motivation) dan keterampilan (skills). Kejahatan asusila dapat dikaitkan dengan mengembangkan pendidikan karakter kepada masyarakat sehingga dapat mengurangi terjadinya kejahatan asusila di masyarakat. Memberikan banyak motivasi dan keterampilan, mengarahkan sikap dan perilaku yang baik. Pendidikan berbasis kearifan lokal mengajarkan untuk selalu lekat dengan situasi konkret yang mereka hadapi. Membangun manusia berpendidikan berlandaskan pada pengakuan eksistensi manusia sejak dalam kandungan, pendidikan harus berbasis kebenaran dan keuhuran budi, pendidikan harus mengebangkan moral.

\section{Kesimpulan}

Berdasarkan hasil penelitian terhadap novel Drupadi karya Seno Gumira Ajidarma dapat disimpulkan bahwa bentuk-bentuk kejahatan sosial yang terjadi di dalam novel yaitu kejahatan perkosaan dan pelecehan seksual. Selain itu peneliti juga menjelas beberapa bentuk kejahatan sosial yang terjadi di masyarakat agar dapat memeberikan informasi dan pemahaman. Bentuk-bentuk kejahatan asusila tersebut terjadi karena beberapa faktor, dalam Novel Drupadi faktor yang menyebabkan terjadinya kejahatan sosial adalah faktor kekuasaan, dimana kekuasaan dapat merampas apa saja yang mereka inginkan dan bertindak semenahmenah. Novel yang berjudul Drupadi karya Seno Gumira Ajidarma berkisah tentang perjalanan hidup Drupadi yang luar biasa. Drupadi sosok wanita cerdas, kuat, dan kelembutannya mampu memberi perlawanan atas penghinaan dan kejahatan asusila yang dilakukan Kurawa. Drupadi digambarkan sebagai wanita poliandri yang hidupnya sengsara tapi ia tetap bersetia kepada takdir. Permasalahan yang disoroti oleh peneliti adalah tentang kejahatan asusila yang terjadi di dalam novel Drupadi karya Seno Gumira Ajidarma. pelecehan seksual adalah penyalagunahan hubungan perempuan dan laki-laki yang merugikan salah satu pihak, karena dilecehkan dan direndahkan martabatnya. Kejahatan asusila sama saja dengan merampas harga diri perempuan. Dari tindakan tersebut juga dapat dikaitkan dengan kurangnya pendidikan karakter di Indonesia.

\section{Daftar Pustaka}

Caterine, dkk. 2012. Perbandingan 
Perilaku Seksual Menyimpang dalam Novel Nayla Tabularasa. Prodi Pendidikan Bahsa dan Sastra Indonesia: Universitas Negeri Padang.

Dewi, Kusuma. 2010. Tinjauan Kritik

Sastra Feminis dalam Novel Mimi Lan Mintuno Karya Remy Syado.Fakultas Sastra dan Seni Rupa:Universitas Sebelas Maret.

Fuadi, Anwar. 2011. Dinamika Psikologis

Kekerasan Seksual: Sebuah Studi Fenomenologi. Fakultas Psikologi: Universitas Islam Negeri Malang.

Kartika, Ayu. 2008. Konflik Batin Tokoh Utama dalam Novel Nayla Karya Djenar Maesa

Ayu: Tinjauan Psikologi Sastra. Fakultas Keguruan dan Ilmu Pendidikan: Universitas Muhammadiyah Surakarta.

Margono, Aris. 2015. Perjuangan Kesetaraan Gender Tokoh Wanita pada Novel-Novel

Karya Abidah El Khalieqy. Prodi Pendidikan Bahasa dan Sastra Indonesia: Universitas Negeri Searang.

Mayasari, Galih. 2010. Asepek Moral dalam Novel Midah Simanis Bergigi Emas Karya Pramoedya Ananta Toer: Tinjauan Sosiologi Sastra. Fakultas Keguruan dan Ilmu Pendidikan: Universitas Muhammadiyah Surakarta.

Pradina, Vivilia. Menanamkan Pendidikan Karakter Berbasis Kearifan Lokal Melalui Pembelajaran Bahasa Jawa. Universitas Negeri Yogyakarta.

Sulistyorini, Dwi. 2010. Pelecehan Seksual Terhadap Tokoh Perempuan dalam Novel Perempuan di Titik Nol karya El-Saadawi dan The Colour Purple Karya Alice Walker. Fakultas Sastra: Universitas Negeri Malang. 